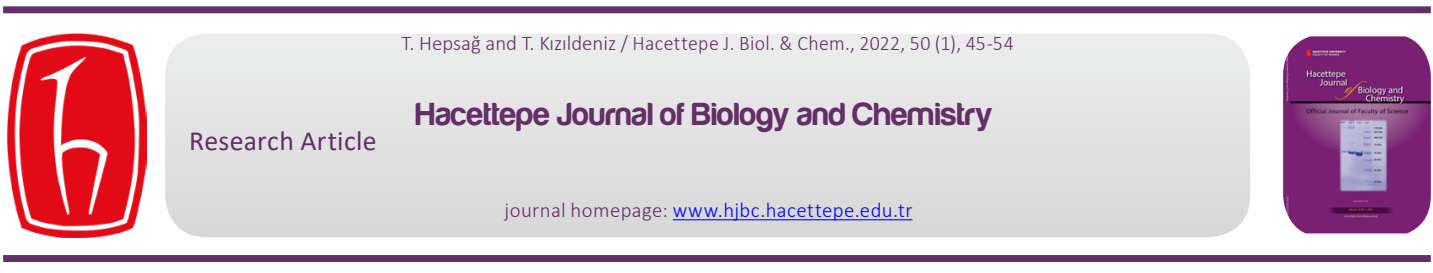

\title{
Validation of Determination by Icp-Oes Method of Mercury Residual Levels in Meat of Canned Fish Put up for Sale in Turkey
}

\section{Türkiye'de Satışa Sunulan Konserve Balık Etlerinde Civa Kalınt Seviyelerinin Icp- Oes Metodu ile Saptanması ve Validasyonu}

\section{Fatma Hepsağ ${ }^{1}$, Tefide Kızıldeniz ${ }^{2}$}

${ }^{1}$ Osmaniye Korkut Ata University, School of Applied Sciences, Department of Food Technology, Kadirli Campus, Osmaniye, Turkey. ${ }^{2}$ Nigde Omer Halisdemir University, Faculty of Agricultural Sciences and Technologies, Biosystem Engineering Department, Nigde, Turkey.

\section{A BSTRACT}

\begin{abstract}
This study describes the residual mercury levels in canned fish marketed in Turkey. In total, 375 fish samples were analyzed by Inductive Coupled Plasma Optical Emission Spectrometry (ICP OES) for mercury residues. The quantification limit (LOQ) from the validation data ranged from 0.008 to $0.043 \mathrm{mg} \mathrm{kg}^{-1}$. Accuracy and precision were evaluated by means of recovery experiments at two concentration levels (30, and $50 \mathrm{mg} \mathrm{kg}^{-1}$ ), obtaining recoveries between $87.5 \%$ and $109.3 \%$ and coefficient of variation below $10 \%$. Also, the relative standard deviation (RSD) ranged from $0.2 \%$ to $9 \%$. The expanded measurement uncertainty for mercury ranged from $11.1 \%$ to $19.2 \%$. In investigated samples, $4.8 \%$ were detected at a detectable level of mercury, but these levels were below the legal limits. With regard to hg level were no significant correlations $(p<0.05$ ) between species. According to Turkey's legislation, none of for example the maximum limit of $1.0 \mathrm{mg} \mathrm{kg-1}$ did exceed the level, but 1.3\% exceeded the limit recommended by the Food and Agriculture Organization/World Health Organization $\left(0.5 \mathrm{mg} \mathrm{kg}^{-1}\right)$. The reproducibility limits obtained as a result of the validation study were found to be appropriate in accordance with both the NMKL 170 method and the Turkish Food Codex (Communiqué No: 2014/2), as well as the EU Commission Decision 2002/657/EC.
\end{abstract}

\section{Key Words}

Mercury, canned fish, ICP-OES, method development.

\section{öz}

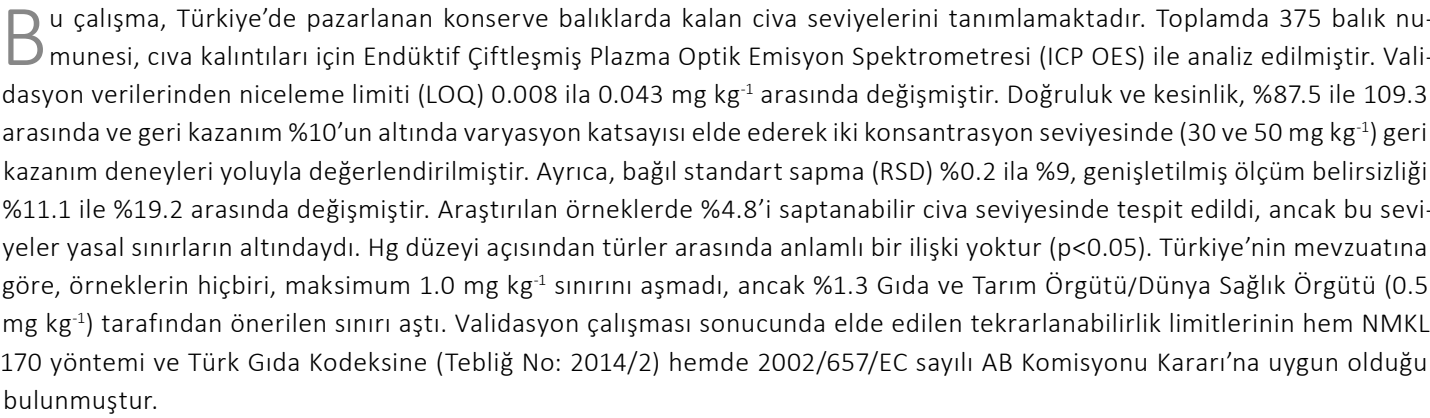

\section{Anahtar Kelimeler}

Civa, konserve balık, ICP-OES, yöntem geliştirme.

Article History: Received: Aug 20, 2020; Revised: May 24, 2021; Accepted: May 24, 2021; Available Online: Jul $20,2021$. DOI: https://doi.org/10.15671/hjbc.778023

Correspondence to: F. Hepsağ, School of Applied Sciences, Department of Food Technology, Osmaniye Korkut Ata University, Osmaniye, Turkey. E-Mail: fatmahepsag@osmaniye.edu.tr 


\section{INTRODUCTION}

- ish and other seafood have become one of the ol- dest food sources of people. In parallel with the development of science and technology, it has been in the diets of people from the first periods of history to the present. Their composition is similar to red meats such as beef, sheep, pork, and meat of poultry; It contains complete proteins, vitamins and minerals, which are considered to be the main nutrients for health, including highly unsaturated fatty acids such as omega-3 and omega-6 [1,2].

One of the most important problems today is the discharge of industrial wastewater into rivers and seas. Chemical wastewater is usually the source of heavy metals. Heavy metals are toxic pollutants that are not biodegradable in the ecosystem. Unfortunately, heavy metals can accumulate in different organs of fish and marine animals and ultimately affect the human food chain [3].

Fish are ideal indicators of heavy metals contaminations in aquatic systems [4], because they are constantly exposed to alloys in polluted waters $[5,6]$, and occupied different trophic levels [4], also may accumulate heavy metals, and represent one of the major sources of heavy metals for human $[1,7]$. The pollution of the aquatic environment has become a worldwide problem during in recent years [8]. Aquatic is the most important of the food chain and is able to concentrate some metals from the water [9]. For example, mercury $(\mathrm{Hg})$ pollutant is one of the most studied elements. The duration of action varies according to age, ambient temperature, salt ratio, $\mathrm{pH}$ and seasonal changes $[10,11]$.

Heavy metals inhibit biological activity by damaging cell functions in living things. Heavy metals are classified as heavy metals ( $\mathrm{Fe}, \mathrm{Cu}, \mathrm{Zn}, \mathrm{Ni}$ and $\mathrm{Se}$ ) which are required to be present at a certain concentration in life and heavy metals $(\mathrm{Hg}, \mathrm{Cd}$ and $\mathrm{Pb}$ ) which have toxic effects from their initial concentrations even at very low concentrations [12]

In terms of toxicity of heavy metals, the risk of people is determined by measuring the metal concentrations of the aquatic species with the highest economic value and the most consumed [9]. If toxic elements are to be taken for a long period, even very low concentrations can be harmful [13]. It is considered as one of the most hazardous metals in Mercury [14].
A lot of mercury is too low to be detected. In contrast, fish and fish products are found in large quantities. Mercury in human and animal organisms in vitro and in vivo by blocking the SH groups of the enzymes that contain the groups and causing damage to the cell membrane. Methylmercury is by far the most common form of organic mercury in the food chain [15]. Mercury is converted into methylciva by bacteria and organisms. Planktons are mixed with big fishes and sea mammals fed with small fishes and mussels and small fish that eat them [16]. The rise in water temperature in summer increases the solubility of mercury in water and increases the concentration of mercury in fish [17]. Almost all of the methylciva in the food passes into the blood. Nervous system, brain damage and kidneys on the heavy damage, recurrent miscarriage, nervous system development disorders in children, has been determined by studies that cause stillbirths [18].

Most human exposure to mercury comes from the diet, and, in particular, through consumption of contaminated fish. Mercury accumulates in fish due to contamination of their marine environment and diet. As such, fish living in contaminated waters, or predatory fish living a long time, are more likely to be contaminated with mercury. According to data available through the FDA, the commercial fish with the highest mercury content are tilefish (1.45 ppm), shark (0.988 ppm), swordfish (0.976 ppm), and mackerel (0.730 ppm). The highest concentration observed was 4.540 ppm, seen in shark samples [19].

Various institutions and organizations, such as the US Food and Drug Administration, the Food and Agriculture Organization (FAO) and the World Health Organization (WHO), limit the human intake of trace elements. The FAO/WHO Committee on Food Additives has determined the daily intake for food additives and some pollutants in food, as well as temporarily acceptable weekly intake (PTWI) values. These determined values are important safety levels for people [20].

On the other hand, canning stays to be a particularly important form of commercial food preservation, and canned tuna constitutes a source of nutritious and relatively inexpensive healthy food, which has long shelf life at ambient temperatures and suitable for worldwide distribution [21]. 
Increasing fish consumption in Turkey has increased the need for assessing the quality of seafood. The aim of this study was to verify the methodologies using quantification with ICP OES and to determine total mercury content in total 375 canned fish samples supplied from the markets in Istanbul, Bursa, Çanakkale, Izmir, Adana, Ankara, Gaziantep in 2016 and 2017.

The template is used to format your paper and style the text. All margins, column widths, line spaces, and text fonts are prescribed; please do not alter them. Your paper is one part of the entire proceedings, not an independent document. Please do not revise any of the current designations.

\section{MATERIALS and METHODS}

\section{Sample collection}

Samples of fish muscle from tuna species skipjack tuna (katsuwonus pelamis) ( $\mathrm{n}=90$ ), bluefin tuna (thunnus thynnus) ( $n=95$ ), yellowfin tuna (thunnus albacares) ( $n=90)$, and albacore tuna (thunnus alalunga) $(n=100)$ were supplied from the markets in Istanbul, Bursa, Çanakkale, Izmir, Adana, Ankara and Gaziantep in 2016 and 2017. The total of 375 samples were transported to the laboratory and were kept frozen $\left(-18{ }^{\circ} \mathrm{C}\right)$ until analysis. All samples were analyzed in triplicate for the presence of total $\mathrm{Hg}$.

\section{Devices, Reagents and Materials}

All glassware was left to stand overnight in 6.5\% (v/v) nitric acid (Merck, Germany), then washed with 10\% (v/v) hydrochloric acid (Merck, Germany), then rinsed with distilled water and dried. Water is treated with reverse osmosis and has a resistance of $18.2 \mathrm{M} \Omega \mathrm{cm}$ 1 . All reagents used, such as hydrogen peroxide, hydrogen chloride, sodium permanganate (Merck, Germany) were at the analytical reagent level. The mercury standard stock solution was prepared from Titrasol (1000 $\mathrm{mg} \mathrm{L}^{-1}$ ) (Merck, Germany) and diluted into the corresponding metal solution. $2 \%$ solution of $\mathrm{HCl}$ (Merck, Germany) was used to prepare the calibration standards. Calibration solutions were prepared with 5 ppb, 10 ppb, $20 \mathrm{ppb}$ and $40 \mathrm{ppb}$ of 10 ppm Hg standard working solution.

Inductively Coupled Plasma-Optical Emission Spectroscopy (ICP-OES) with radial torch equipped with argon saturation assembly was used for the determination of mercury. The Vista - MPX CCD Simultaneous ICP
OES was purchased from Varian Inc (Mulgrave Victoria, Australia). High purity (99.9\%) argon was used as plasma, auxiliary and nebulizer gas (Air Liquid, SP, Brezilya). the gas flows were kept at $15.0 \mathrm{~L} \mathrm{~min}^{-1}$ for plasma, $1.5 \mathrm{~L} \mathrm{~min}^{-}$ ${ }^{1}$ for auxiliary and $0.56 \mathrm{~L} \mathrm{~min}^{-1}$ for nebulizer. Radio frequency (R.F) power of the plasma generator was 1300 watts. Vertical height of the plasma was fixed at $7 \mathrm{~mm}$. It was employed $25 \% \mathrm{SnCl}_{2}(\mathrm{~m} / \mathrm{v})$ solution as reductant.

\section{Analytical procedures for estimation of total $\mathbf{~ H g}$}

The basis of the analysis is based on the principle of detecting the mercury concentration by ICP-OES after reducing the amount of $\mathrm{Hg}$ in the samples with sodium borohydride to the element mercury by burning the samples in the microwave with nitric acid. Each sample was milled and homogeneously mixed in the blender. From the homogenized sample, about $1 \mathrm{~g}$ was weighed into the teflon sample incinerator. Then, $10 \mathrm{ml}$ of $\mathrm{HNO}_{3}$ (65\% purity), 2-3 drops of $\mathrm{H}_{2} \mathrm{O}_{2}$ (30\%) was added to the fume hood for 20 minutes. At the end of the period, the lids of the teflon containers were closed and placed in the microwave burner. At the end of the burning process lasting 1 hour, the containers were removed and rested for 20 minutes. The contents of the containers were transferred to the flask. Then the level of ultrapure water was completed and filtered and diluted with acid-resistant filter paper [22].

\section{Validation and uncertainty calculation}

The parameters for validation are as follows. The limit of determination, the limit of measurement, linear measuring range, precision, repeatability, reproducibility, accuracy (reality), recovery. For the validation of mercury analysis in all canned fish samples; canned fish were used as qualification test material. Concentrations were determined from the selected sample. Studies were carried out at the determined concentrations. The limit of determination (LOD) and the measurement limit (LOQ) were calculated according to the second edition of Eurachem 201 The Fitness for purpose of Analytical Methods for Second Edition 2014.

\section{Statistical Analysis}

The results of the mercury concentration in canned fish were transferred to Microsoft Excel spread sheet (Microsoft Corp. Redmond, WA, USA) for analysis. One-way analysis of variance (ANOVA) was implemented using SPSS version 16 software to test the significance of contaminating trace elements level variations among the fish canned samples. The statistical significance level was set at $p<0.05$ for all tests. 
Table 1. Enantiomeric separations using cyclodextrins (CDs) and derivatives as chiral selectors.

\begin{tabular}{cccccc}
\hline Element & $\lambda(\mathrm{nm})$ & $r$ & $\begin{array}{c}\text { Straight line } \\
\text { equation }\end{array}$ & $\begin{array}{c}\text { Sensitivity }(\mathrm{L} \\
\left.\mathrm{mg}^{-1}\right)\end{array}$ & $\begin{array}{c}\mathrm{LOD} \\
\left(\mu \mathrm{L}^{-1}\right)\end{array}$ \\
\hline $\mathrm{Hg}$ & 192.30 & $\mathrm{Y}=14748.7 \mathrm{xO}+$ & 14567 & $0.1^{*}$ \\
\hline
\end{tabular}

*Statistical significance: $p<0.05$. LOQ: Limit of Quantitation

\section{RESULTS}

\section{Method validation}

For the purpose of mercury analysis within the scope of the method validation, the method is used to calculate the limit of, measurement limit, linear measurement range, accuracy, reproducibility, reproducibility, accuracy and recovery values; For the main component analysis, the results of the analyzes with canned fish samples were calculated and the reproducibility values of the results were calculated. Correlation coefficients and sensitivity values are shown in Table 1 . We can observe that values obtained for correlation coefficients are above 0.9997 for all elements, suggesting a good linearity of analytical curves in work ranges defined. The parameters and calculation techniques used in method validation studies are presented below.

Determination limit (LOD) and measurement limit (LOQ) Mercury standards (0.005ppm-0.01ppm-0.02ppm$0.04 \mathrm{ppm}$ ) were prepared for the determination limit (LOD) and measurement limit (LOQ) operation. Calibration curve was created on the device. After the addition of acid to each of the 20 different teflon sample containers which were applied to each sample without using a sample (reagent), the mercury concentration that the device was able to read with the least deviation was calculated and spiked into each container and the incineration was performed. The dilution was applied to the sample and the mercury was read. According to Eurachem The fitness for purpose of Analytical Methods pose Second Edition 2014 using the values of twenty different mercury mean values, the determination limit (LOD) and measurement limit (LOQ) were calculated. Average recovery rate was $97 \pm 2 \%$ for mercury.

\section{Linear Measuring Range}

In order to determine the linear measuring range, 4 different concentrations of mercury mineral were made and the following Figure 1. graph was obtained.

\section{Repeatability and Repeatability Limit}

For this purpose, a total of 46 recovery studies were carried out by 3 analysts for mercury analysis, 2 for fish sample and 2 different concentrations for this matrix. The repeatability limit was calculated for each of the 3 analysts according to the following formula: $r=2.8 \times \mathrm{Sr}$ Reproducibility and Reproducibility Limit

For this purpose, a total of 36 recovery studies were carried out by 3 analysts in 2 different concentrations of mercury mineral, fish sample and this matrix. The reproducibility limit is calculated according to the following formula: $\mathrm{R}=2.8 \times \mathrm{Sr}$

\section{Accuracy and Recovery}

The reality work for accuracy is done by recovery. For recovery, 3 analysts conducted a total of 59 gains in the following concentrations: Results and calculated \% recovery results are given the Table 2 . The recovery rate was calculated according to the following formula: $\% R=[(C F-C U) / C A] \times 100$

\section{Uncertainty calculation}

Uncertainty of analytical methodology to determine inorganic contaminants was estimated for the main factors that aggregate variations in methodology such as uncertainty from sample weighing, uncertainty from sample volume, uncertainty from standard preparation, uncertainty from the calibration curve, uncertainty from personnel, uncertainty from combustion containers, uncertainty from incineration as per guidelines EURACHEM 2002. The uncertainty from precision, the relative standard deviation calculated for each matrix and for each concentration of reproducibility studies were taken as certainty uncertainty. The uncertainty from accuracy, the difference from the mean of the regression study was found to be significant from 1 and the uncertainty from accuracy was calculated by the following 1, 2, 3 with formulas. 
Table 2. Results and calculated \% recovery.

\begin{tabular}{|c|c|c|c|c|}
\hline & $\begin{array}{c}\text { Added concentration } \\
0.5 \mathrm{ppm} \mathrm{Hg} \\
\text { Achieved concentration } \\
\left(\mathrm{mgkg}^{-1}\right)\end{array}$ & \%Recovery & $\begin{array}{c}\text { Added concentration } \\
0.3 p p m ~ H g \\
\text { Achieved concentration } \\
\left(\mathrm{mgkg}^{-1}\right)\end{array}$ & \%Recovery \\
\hline & 0.478 & 95.72 & 0.261 & 87.45 \\
\hline & 0.457 & 91.54 & 0.267 & 89.56 \\
\hline & 0.467 & 93.52 & 0.289 & 96.85 \\
\hline & 0.469 & 92.15 & 0.287 & 96.28 \\
\hline & 0.381 & 76.28 & 0.265 & 88.66 \\
\hline & 0.398 & 79.76 & 0.274 & 90.56 \\
\hline & 0.417 & 83.54 & 0.293 & 98.12 \\
\hline & 0.403 & 80.68 & 0.294 & 98.29 \\
\hline & 0.416 & 83.28 & 0.291 & 97.42 \\
\hline & 0.527 & 105.52 & 0.292 & 97.85 \\
\hline & 0.461 & 92.57 & 0.278 & 93.27 \\
\hline & 0.512 & 101.82 & 0.294 & 98.32 \\
\hline \multirow[t]{13}{*}{$\mathrm{Hg}$} & 0.497 & 99.56 & 0.286 & 95.91 \\
\hline & 0.507 & 101.46 & 0.287 & 96.15 \\
\hline & 0.505 & 101.14 & 0.299 & 100.54 \\
\hline & 0.487 & 97.57 & 0.326 & 109.26 \\
\hline & 0.504 & 100.86 & 0.326 & 109.26 \\
\hline & 0.502 & 100.58 & 0.317 & 106.22 \\
\hline & 0.512 & 102.18 & 0.318 & 106.52 \\
\hline & 0.494 & 98.86 & 0.318 & 106.65 \\
\hline & 0.47 & 94.69 & 0.322 & 107.72 \\
\hline & 0.474 & 94.94 & 0.321 & 107.55 \\
\hline & 0.461 & 92.34 & 0.299 & 100.06 \\
\hline & 0.502 & 100.54 & 0.282 & 94.34 \\
\hline & 0.503 & 100.63 & 0.293 & 98.12 \\
\hline MEAN & 0.471 & 94.54 & 0.295 & 98.76 \\
\hline
\end{tabular}

Table 3. Combined and expanded uncertainty applied to analysis of certified reference material, $k=2$

\begin{tabular}{cccc}
\hline $\begin{array}{c}\text { Mean achieveda } \\
\left(\mathrm{mg} \mathrm{kg}^{-1}\right)\end{array}$ & $\begin{array}{c}\text { Combined standard } \\
\text { uncertainty }\left(\mathrm{mg} \mathrm{kg}^{-1}\right)\end{array}$ & $\begin{array}{c}\text { Combined standard } \\
\text { uncertainty }(\%)\end{array}$ & $\begin{array}{c}\text { Expanded standard } \\
\text { uncertainty }\left(\mathrm{mg} \mathrm{kg}^{-1}\right)\end{array}$ \\
\hline Mercury & $0.039^{*}$ & 0.021 & 5.67 \\
\hline
\end{tabular}

*Statistical significance: $p<0.05$. LOQ: Limit of Quantitation. 
Table 4. Combined and expanded uncertainty applied to analysis of certified reference material, $k=2$.

\begin{tabular}{|c|c|c|c|c|c|}
\hline Samples & $\begin{array}{c}\text { Mean } \\
\left(\mathrm{mg} \mathrm{kg}^{-1}\right)\end{array}$ & $\begin{array}{l}\text { Standart devition } \\
\qquad\left(\mathrm{mg} \mathrm{kg}^{-1}\right)\end{array}$ & $\begin{array}{c}\text { Standart error } \\
\left(\mathrm{mg} \mathrm{kg}^{-1}\right)\end{array}$ & $\begin{array}{l}\text { Minumum } \\
\left(\mathrm{mg} \mathrm{kg}^{-1}\right)\end{array}$ & $\begin{array}{l}\text { Maximum } \\
\left(\mathrm{mg} \mathrm{kg}^{-1}\right)\end{array}$ \\
\hline Canned skipjack tuna & 0.381 & 0.264 & $0.063^{*}$ & $0.09 *$ & 0.66 \\
\hline Bluefin Tuna & 0.274 & 0.189 & $0.042 *$ & $0.08^{*}$ & 0.51 \\
\hline Yellowfin Tuna & 0.174 & 0.135 & $0.036 *$ & $0.04^{*}$ & 0.53 \\
\hline Albacore Tuna & $0.079 *$ & $0.054^{*}$ & $0.011^{*}$ & $<\mathrm{LOQ}$ & 0.22 \\
\hline
\end{tabular}

*Statistical significance: $p<0.05$. LOQ: Limit of Quantitation

$$
t=\frac{\mathrm{I} 1-\overline{\mathrm{R}} \mathrm{I}}{\mathrm{u}(\overline{\mathrm{R}})}
$$

$$
\mathrm{u}\left(\mathrm{R}_{\mathrm{a}}\right)=\sqrt{\left(\frac{1-\overline{\mathrm{R}}}{\mathrm{k}}\right)^{2}+\mathrm{u}(\overline{\mathrm{R}})^{2}}
$$

$\mathrm{u}(\mathrm{R})=\frac{\text { tkrit } \times \mathrm{u}(\overline{\mathrm{R}})}{1.96}$

Table 3 shows results obtained for $\mathrm{Hg}$ in 375 samples analyzed. In Turkey, the maximum levels of inorganic contaminant in fish are established by the Turkish Food Codex and the Ministry of Agriculture and Forestry. For fish and fishing products, the maximum tolerance levels are: $\mathrm{Hg}=1 \mathrm{mg} \mathrm{kg}^{-1}$. Considering the boundaries of the Turkish Food Codex legislation from the sample of 102 canned fish samples, there was no level above the maximum tolerance limit for $\mathrm{Hg}$.

The $\mathrm{Hg}$ content of all samples was found at different measurable levels (Table 3 ), the value of the smallest $\mathrm{Hg}\left(0.046 \pm 0.845 \mathrm{mg} \mathrm{kg}^{-1} \mathrm{ww}\right)$, the highest value of $\mathrm{Hg}$ $\left(0.382 \pm 0.153 \mathrm{mg} \mathrm{kg}^{-1} \mathrm{ww}\right)$. However, no significant difference was found between canned fish samples. The maximum level accepted for $\mathrm{Hg}$ in canned fish (1 mg $\mathrm{kg}^{-1}$ weight) [23].

\section{Determination of $\mathrm{Hg}$ level}

The results of the present investigation showed that canned fish were contaminated with mercury heavy metal. Hg content in all canned fish was found at different measurable levels (Table 4), the average value of $\mathrm{Hg}$ in canned skipjack tuna (0.381 $\left.\pm 0.005 \mathrm{mg} \mathrm{kg}^{-1} \mathrm{ww}\right)$, for bluefin tuna $\left(0.274 \pm 0.005 \mathrm{mg} \mathrm{kg}^{-1} \mathrm{ww}\right)$, for yellowfin tuna $\left(0.173 \pm 0.005 \mathrm{mg} \mathrm{kg}^{-1} \mathrm{ww}\right)$ and albacore tuna $\left(0.079 \pm 0.005 \mathrm{mg} \mathrm{kg}^{-1} \mathrm{ww}\right)$ [23]. However, none of the samples analyzed had mercury levels above the maximum limit.

\section{DISCUSSION}

\section{Comparison with reported literature values}

The precision and accuracy of the method was tested using repetitive spike of a sample and finally, the appropriate recovery was confirmed (Table 2 ). The limit of detection (LOD) of mercury are 0.5 and 0.3 ppm for canned fish samples, respectively.

Regular monitoring of mercury contamination in fish and fish cans, or limitation of residual residues, and the residual analyzes carried out accordingly are the leading control methods of the state [24].

In a studie conducted in Al-Busaidi et al., in 2011 found the $\mathrm{Hg}$ level ranged from 0.015 to $0.110 \mathrm{mg} \mathrm{kg}^{-1}$, in freshed and frozen marine fish and none of the samples exceeded the EU limit [25]. Hajeb et al., in 2009 studied $\mathrm{Hg}$ level in commonly consumed marine fishes in Malaysia and the tuna species had the highest level (4.15 $\mu \mathrm{g} \mathrm{g}^{-1}$ ) [26]. In America, Gerstenberger et al., in 2010 examined the levels of total mercury in a New Jersey grocery store $\mathrm{Hg}\left(0.407 \mathrm{mg} \mathrm{g}^{-1}\right)$ was found in the canned white-style tuna than canned light-style tuna $(0.118 \mathrm{mg}$ $\left.\mathrm{g}^{-1}\right)$ [27]. In studies conducted in Spain, Bordajandi et al., in 2004 found $\mathrm{Hg}$ levels of 0.30 and $0.28 \mathrm{mg} \mathrm{kg}^{-1}$ in canned and frozen tuna, respectively [28]. Blanco et al., in 2008 also studied $\mathrm{Hg}$ in canned and frozen tuna, having obtained values ranging from $<0.10$ to 0.87 and from $<0.10$ to $0.49 \mathrm{mg} \mathrm{kg}^{-1}$, respectively [29]. In Austria, $\mathrm{Hg}$ concentration was found to be $0.048 \mathrm{mg} \mathrm{g}^{-1}$ in canned tuna samples collected from grocery stores. In countries sold in Italy, 8.9\% of tuna canned food [30] and $33.3 \%$ in Spain exceeded the European legal limits for $\mathrm{Hg}$ within the limits set by the EU. 


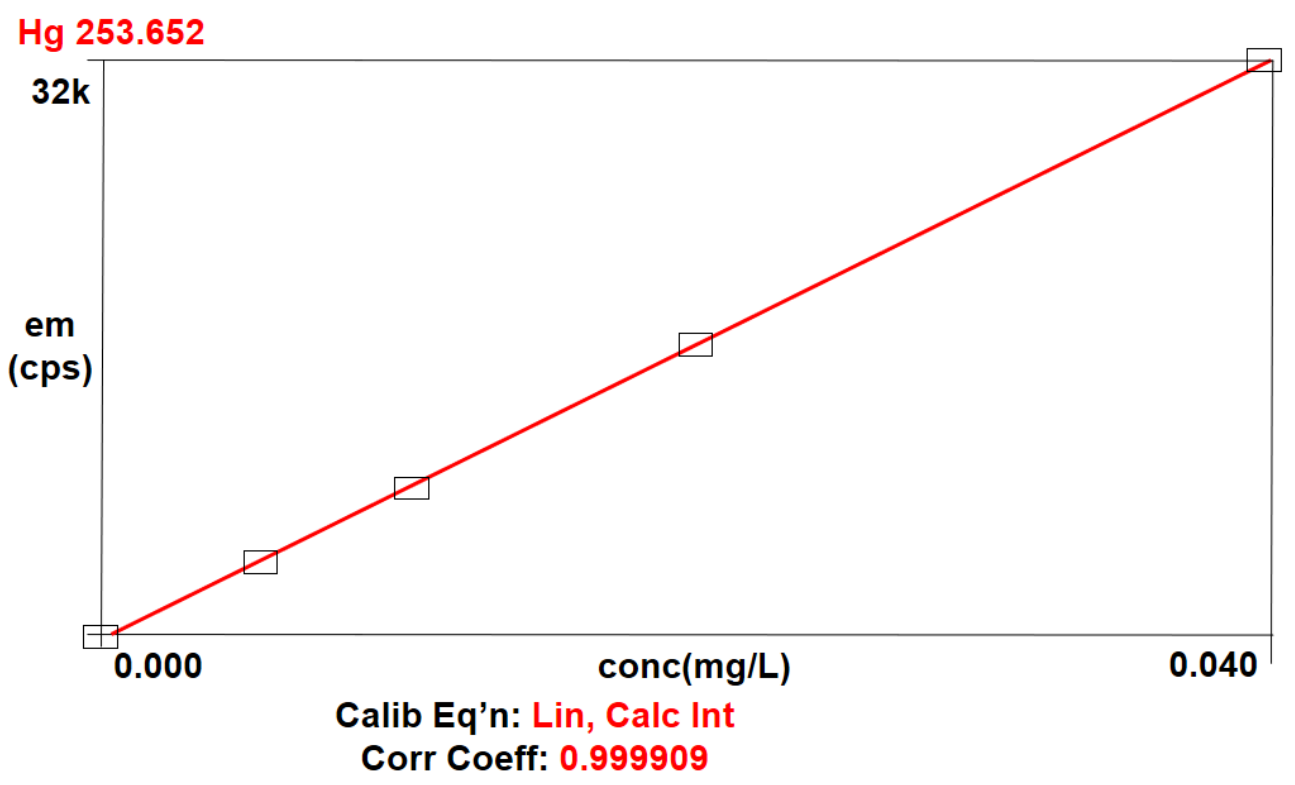

Figure 1. Linear measuring range.

In many studies conducted on canned tuna fish produced and marketed in Iran, Hg concentrations were significantly lower than those determined by FAO/WHO [31,32]. Abolghait et al., in 2015 examined mercury levels in Italy, Libya, Spain and Thailand. Hg concentrations were between $0.163-0.373 \mathrm{mg} \mathrm{g}^{-1}$ [5]. In the United States, Ikem et al., in 2005 also studied total Hg presence in canned tuna, and observed values ranging from 0.05 to $0.74 \mathrm{mg} \mathrm{kg}^{-1}$ [33]. Such values are lower than those obtained in a study conducted by Zhang et al., 2001, which have observed $\mathrm{Hg}$ values varying from 0.025 to $0.137 \mathrm{mg} \mathrm{kg}^{-1}$ for canned salmon [34]. Mol in 2011 found a higher maximum level of $1.14 \mathrm{mg} \mathrm{kg}^{-1} \mathrm{Hg}$ in canned tuna produced in Turkey than in the present study [35]. Unusual high $\mathrm{Hg}$ level of $2.93 \mathrm{mg} \mathrm{kg}^{-1} \mathrm{Hg}$ ww was reported in canned yellowfin in Taiwan [36]. Lowenstein et al., in 2010 analyzed samples from different tuna species sold in New York, New Jersey and Colorado restaurants and supermarkets [37]. The authors have observed Bigeye Tuna (Thunnus obesus) species exhibited the highest levels of $\mathrm{Hg}(0.365-2.254 \mathrm{mg} \mathrm{kg}$ $\left.{ }^{1}\right)$. Canned tuna fish from the Mediterranean coast of Libya had $\mathrm{Hg}$ levels well below the permissible limits at range from 0.20 to 0.66 with an average value of 0.29 $\mathrm{mg} \mathrm{kg}^{-1} \mathrm{ww}$ [38]. The concentration of $\mathrm{Hg}$ in skipjack tuna caught off Eastern Pacific Ocean and in front of the Baja California Peninsula was $0.104 \mathrm{mg} \mathrm{kg}^{-1}$ ww [39].
The season which the seafood samples were collected and analyzed for presence of heavy metals is another determinative factor in the concentration of toxic elements. It seems that different seasonal dependent conditions such as water temperature, dietary factors and growth and reproductive cycles are effective on heavy metal fluctuations. The higher metal content in winter might be a result from considerable rainfall which washed down the wastes $[40,41]$.

Regarding the existing law for $\mathrm{Hg}$, the European Community, Canada, and the FDA establish a total $\mathrm{Hg}$ level of $1 \mathrm{mg} \mathrm{kg}^{-1}[42,43]$. Japan sets forth limit values of 0.4 $\mathrm{mg} \mathrm{kg}^{-1}$ [44], whereas in Brazil and Turkey limit values are $0.5 \mathrm{mg} \mathrm{kg}^{-1}$ for non-predator fishes and $1.0 \mathrm{mg} \mathrm{kg}^{-1}$ for predator ones [4].

The results of this study showed that canned fish samples obtained from grocery stores were significantly contaminated with mercury heavy metal. However, the levels of this toxic element are generally lower than their permissible levels, but the consumption of contaminated seafood even below permissible levels may be detrimental to human health. One of the most important points to assess the levels of mercury heavy metal in seafood is the comparison of the allowable scope and the acceptance of the daily intake of heavy 
metal with the amount obtained. The recommended acceptance limits for mercury are $0.5 \mathrm{mg} \mathrm{kg}^{-1}[45,46]$ The highest mercury level determined in our study were $45.33 \mu \mathrm{g} \mathrm{g}^{-1}$. The levels of the detected elements were lower than the recommended acceptable limits. However, monitoring of a continuous $\mathrm{Hg}$ concentration in canned fish products is essential for food safety.

One possible explanation for the lower mercury content in our results is the fact that our study is not in close contact with pollutant sources, such as oil tankers and industrial wastewaters. In addition, the differences between the races in the study of seafoods investigated in our study are another reason for the fact that the samples used in our study are canned fish, ie the prevalence of heavy metals is lower.

\section{CONCLUSIONS}

As a result, an important part of our world has been contaminated with mercury in the last half-century, and it is a fact that pollution is concentrated especially in closed seas and inland waters. Mercury impurities accumulate at increasing concentrations throughout the food chain and threaten all kinds of living things. For these reasons determination of mercury residue levels in our foods, accelerating the studies that can be taken without harm, and taking the necessary measures without delay to determine the causes of pollution has become a definite necessity.

The levels of trace metals in fish samples widely used in Turkey cuisine (skipjack tuna, bluefin tuna, yellowfin tuna and albacore Tuna) marketed in Turkey were determined and assessed for their quality by comparing element levels in samples with maximum permitted levels stipulated by different agencies and organizations. The result from this study suggested that differences existed in the element concentrations even within the same fish species.

As a result, for four species assessed in this study have not shown $\mathrm{Hg}$ concentration levels above the limit established by the Turkey law; however, for hg all species have demonstrated concentrations below permitted levels, which is compliant with results obtained in other studies. In addition, analytical data obtained from this study shows that the metal concentrations for the varieties of canned fishes especially mercury were generally lower than the FAO/WHO, FDA and U.S. EPA recommended limits for fish [47]. Canned therefore, monitoring of these products is important with respect to toxic elements affecting human health. Based on the results obtained, that there is no risk in canned fish with respect to the concentrations of mercury. However, it was observed that some samples may contain close to the legal limits determined by the health authorities. These results may provide useful information for assessing toxic metal uptake. These data could be used as a baseline for monitoring future changes in trace metal concentrations in fish as the population of this region grows. Also, this study will help to generate the data needed for surveillance programs aimed at ensuring the safety of the food supply and minimizing human exposure to toxic metals.

\section{Conflict of interest}

There are no conflicts of interest that are directly or indirectly related to the present study.

\section{References}

1. A. Baysal, Nutrition. Hatiboğlu Publications. Edition, 9, 123150, Ankara, 2002.

2. B. Kumar, D.P. Mukherjee, S. Kumar, M. Mishra, D. Prakash, S.K. Singh, and C.S. Sharma, Bioaccumulation of heavy metals in muscle tissue of fishes from se-lected aquaculture ponds in east Kolkata wetlans. Annals of Biological Research, 2 (2011) 125-134.

3. S. Miniadis-Meimaroglou, C. Dimizas, V. Loukas, A. Moukas, A. Vlachos, N. Thomaidis, V. Paraskevopoulou, and M. Dasenakis, Proximate composition, fatty acids, cholesterol, minerals in frozen red porgy. Chem. Phys. Lipids, 146 (2007) 104-110.

4. ANVISA (National Agency for Sanitary Vigilance), Tolerance limits of inorganic contaminants in food. Ordinance № 685 of August, Brazil 1998.

5. S.K. Abolghait, and A.M. Garbaj, Determination of cadmium, lead and mercury residual levels in meat of canned light tuna (Katsuwonus pelamis and Thunnus albacares) and fresh little tunny (Euthynnus alletteratus) in Libya, Open Vet. J., 5 (2015) 130-137.

6. M.A. Ashraf, M.J. Maah, and I. Yusoff, Bioaccumulation of heavy metals in fish species collected from former tin miningcatchment, Int. J. Environ. Res., 6 (2012) 209-218.

7. J. Aucoin, R. Blanchard, and C. Billiot, Trace metals in fish and sediments from Lake Boeuf, South Eastern Louisiana. Microchem J., 62 (1999) 299-307.

8. M. Al-Busaidi, P. Yesudhason, S. Al-Mughairi, W.A.K. Al-Rahbi, K.S. Al-Harthy, N.A. Al-Mazrooei, and S.H. Al-Habsi, Toxic metals in commercial marine fish in Oman with reference to national and international standards. Chemosphere, 85 (2011) 67-73.

9. S.A. Mansour, and M.M. Sidky, Exotoxicological Studies. Heavy metals contaminating water and fish from Fayoum Governorate, Egypt, Food chemistry, 8 (2002) 15-22.

10. M.A. Ashraf, M.J. Maah, and I. Yusoff, Bioaccumulation of heavy metals in fish species collected from former tin miningcatchment, Int. J. Environ. Res., 6 (2012) 209-218. 
11. L. Mhadhbi, A. Palaca, T. Gharred, and M. Boumaiza, Bioaccumulation of metals in tissues of SoleaVulgaris from the outer coastand Ria de Vigo, NE Atlantic (Spain), Int J. Environ. Res., 6 (2012) 19-24.

12. C. Bliefert, Umweltchemie. Auflage, Wiley-UCH 2004.

13. U. Çelik, and J. Oehlenschlager, High contents of cadmium, lead, zinc and copper in popular fishery products sold in Turkish supermarkets, Food control, 18 (2005) 258-261.

14. B. Pérez-Cid, C. Boia, L. Pombo, and E. Rebelo, Determination of trace metals in fish species of the Ria de Aveiro (Portugal) by electrothermal atomic absorption spectrometry. Food Chem., 75 (2001) 93-100.

15. EFSA (European Food Safety Authority), Scientific opinion on the risk for public health related to the presence of mercury and methylmercury in food. Efsa J., 10 (2012) 2984-2985.

16. A. Güven, Ö. Kahvecioğlu, G. Kartal, and S. Timur, Environmental effects of metals - III, Metallurgical Journal, 17 (2004) 64-71.

17. A. Gül, M. Yılmaz, and M. Selvi, The study of the toxic effects of mercury-II-chloride, G. Ü. Journal of Science, 17 (2004) 53-58.

18. I. Çok, T.C. Durmaz, E. Durmaz, M.H. Satıroglu, and C. Kabukcu, Determination of organochlorine pesticide and polychlorinated biphenyl levels in adipose tissue of infertile men, Environ. Monit. Assess, 162 (2010) 301-309.

19. D.E.K. Dabt, J. Berger-Ritchie, and G.A. McMillin, Testing for toxic elements: a focus on arsenic, cadmium, lead, and mercury, Lab. Med., 42 (2011) 735-742.

20. Cot, Cot-Committee on Toxicity Advise on fish consumption: Benefits and risks. Food Standards Agency and the Department of Health. Her Royal Majesty's Stationary, Norwich, UK, 2004.

21. L. Bratt, Fish Canning Handbook. Wiley-Blackwell, 2010.

22. M.A. Morgano, P.C. Gomes, D.M.B. Mantovani, A.A.M. Perrone, and T.F. Santos, Níveis de mercúrio total em peixes de água doce de pisciculturas paulistas Ciência e Tecnologia de Alimentos, 25 (2005) 250-253.

23. European Commission, Commission regulation (EC) No. $629 / 2008$ of 2 July 2008 amending Regulation (EC) No $1881 / 2006$ setting maximum levels for certain contaminants in foodstuffs. Off. F. EU, 51 (2008) 4-10.

24. H.R. Yang, N.Y. Kim, L.H. Hwang, J.S. Park, and J.H. Kim, Mercury contamination and exposure assessment of fishery products in Korea. Food Addit. Contam. B. 8 (2015) 44-49.

25. M. Al-Busaidi, P. Yesudhason, S. Al-Mughairi, W.A.K. Al-Rahbi, K.S. Al-Harthy, N.A. Al-Mazrooei, and S.H. Al-Habsi, Toxic metals in commercial marine fish in Oman with reference to national and international standards. Chemosphere, 85 (2011) 67-73.

26. P. Hajeb, S. Jinap, A. Ismail, A.B. Fatimah, B. Jamilah, and M.A. Rahim, Assessment of mercury level in commonly consumed marine fishes in Malaysia, Food Control, 20 (2009) 79-84.

27. S.L. Gerstenberger, S.A. Mueting, and W.H. Wong, Veligers of invasive quagga mussels (Dreissena bugensis) in Lake Mead, Nevada-Arizona. Journal of Shellfish Research, 30 (2011) 933-938.

28. L.R. Bordajandi, G. Gómez, E. Abad, J. Rivera, M.M. FernándezBastón, and J. Blasco, Survey of Persistent Organochlorine contaminants (PCBs, PCDD/Fs, and PAHs), heavy metals ( $\mathrm{Cu}$, $\mathrm{Cd}, \mathrm{Zn}, \mathrm{Pb}$, and $\mathrm{Hg}$ ), and arsenic in food samples from Huelva (Spain): levels and health Implications Journal of Agricultural and Food Chemistry, 52 (2004) 992-1001.

29. S.L. Blanco, J.C. González, and J.M. Vieites, Mercury, cadmim and lead levels in samples of the main traded fish and shelfish species in Galicia, Spain Food Additives and Contaminants: Part B, 1 (2008) 15-21.
30. M.M. Storelli, G. Barone, G. Cuttone, D. Giungato, and R. Garofalo, Occurrence of toxic metals $(\mathrm{Hg}, \mathrm{Cd}$ and $\mathrm{Pb})$ in fresh and canned tuna: public health implications. Food Chem. Toxicol., 48 (2010) 3167-3170.

31. E. Rahimi, and A. Behzadnia, Determination of mercury in fish (Otollithes ruber) and canned tuna fish in Khuzestan and Shiraz, Iran. World Appl. Sci. J., 15 (2011) 1553-1556.

32. S. Andayesh, M.R. Hadiani, Z. Mousavi, and S. Shoeibi, Lead, cadmium, arsenic and mercury in canned tuna fish marketed in Tehran, Iran. Food Addit. Contam. Part B Surveill., 8 (2015) 93-98.

33. A. Ikem, and N.O. Egiebor, Assessment of trace elements in canned fishes (mackerel, tuna, salmon, sardines and herrings) marketed in Georgia and Alabama (United States of America). J. Food Compost. Anal., 18 (2005) 771-787.

34. X. Zhang, A.S. Naidu, J.J. Kelley, S.C. Jeewett, D. Dasher, and L.R. Duff, Baseline concentration of total mercury and methylmercury in salmon returning via the Bering Sea (1999-2000). Marine Pollution Bulletin, 42 (2001) 993-997.

35. S. Mol, Levels of selected trace metals in canned tuna fish produced in Turkey. J. Food Composit. Anal., 24 (2011) 6669.

36. B. Han, W.L. Jeng, R.Y. Chen, G.T. Fang, T.C. Hung, and R.J. Tseng, Estimation of target hazard quotients and potential health risks for metals by consumption of seafood in Taiwan. Arch. Environ. Contam. Toxicol., 35 (1998) 711-720.

37. J.H. Lowenstein, J. Burger, C.W. Jeitner, G. Amato, S.O. Kolokotronis, and M. Gochfelf, DNA barcodes reveal speciesspecific mercury levels in tuna sushi that pose a health risk to consumers. Biology Letters, 6 (2010) 692-695.

38. R.B. Voegborlo, A.M. El-Methnani, and M.Z. Abedin, Mercury, cadmium and lead content of canned tuna fish. Food Chem., 67 (1999) 341- 345.

39. J. Ruelas-Inzunza, M. Soto-Jiménez, A. Ruiz-Fernández, H. Bojórquez-Leyva, H. Pérez-Bernal, and F. Páez-Osuna, Activity and Concentrations of Selected Trace Elements (As, $\mathrm{Cd}, \mathrm{Cu}, \mathrm{Hg}, \mathrm{Pb}, \mathrm{Zn}$ ) in the Muscle Tissue of Tunas Thunnus albacares and Katsuwonus pelamis from the Eastern Pacific Ocean. Biol. Trace Elem. Res., 149 (2012) 371-376.

40. S.S. Saei-Dehkordi, A.A. Fallah, and A. Nematollahi, Arsenic and mercury in commercially valuable fish species from the Persian Gulf: Influence of season and habitat. Food Chem. Toxicol., 48 (2010) 2945-2950.

41. M. Dural, M.Z.L. Göksu, and A.A. Özak, Investigation of heavy metal levels in economically important fish species captured from the Tuzla lagoon. Food Chem., 102 (2007) 415-421.

42. FDA, Guidance for industry: Action levels for poisonous or deleterious substances in human food and animal feed. Available from. http://www.fda.gov/Food/GuidanceCompliance Regulatory Information/Guidance Documents/ Chemical Contaminants and Pesticides/ucm 077969.htm Accessed 19.05.10. 2000.

43. Health Canada, Human health risk assessment of mercury in fish and health benefits of fish consumption Available from. http://hc-sc.gc.ca/fn-an/pubs/mercur/merc_fish_poissoneng.phpAccessed 19.05.10. 2007.

44. Y. Yamashita, Y. Omura, and E. Okazaki, Total mercury and methylmercury levels in commercially important fishes in Japan. Fisheries Science, 71 (2005) 1029-1035.

45. European Commission. 2005. Commission regulation as regards heavy metals. Amending Regulation, 466/2001, No. $78 / 2005$. 
54 | T. Hepsağ and T. Kızıldeniz / Hacettepe J. Biol. \& Chem., 2022, 50 (1), 45-54

46. D. Mergler, H.A. Anderson, L. H. M. Chan, K.R. Mahaffey, M. Murray, M. Sakamoto, and H. Stern, Methylmercury exposure and health effects in humans: A worldwide concern. Ambio, 36 (2007) 3-11.
47. J. Aucoin, R. Blanchard, and C. Billiot, Trace metals in fish and sediments from Lake Boeuf, South Eastern Louisiana. Microchem J., 62 (1999) 299-307. 